\title{
En brydningstid for kvalitet
}

Dansk Universitetspædagogisk Tidsskrift befinder sig i en brydningstid og i et dilemma. Dilemmaet består i at finde en balance mellem på den ene side, erfaringsudveksling, og på den anden side, teoretisk og empirisk baserede analyser og diskussioner inden for det universitetspædagogiske felt.Vi ønsker i tidsskriftet at give plads til gode ideer og praksisser, men vi ønsker at gøre det på en måde, så didaktiske og teoretiske analyser danner grundlag for diskussion og begrundelse af ideer og praksis. Universitetspædagogikken er et forskningsfelt, som kun kan opnå dybde og status ved netop at blive behandlet som et forskningsområde. Derfor er det vigtigt, at hovedparten af de artikler, der publiceres, gennnemgår et videnskabeligt peer review. Som i andre videnskabelige tidsskrifter skal der også være plads til ikke reviewede indlæg $i$ form af formidling af undervisningspraksis, debatindlæg, anmeldelser og reportager. I dette nummer af DUT er der eksempler på det hele. Grunden til, at hovedparten af artiklerne i tidsskriftet skal være peer reviewede artikler er ikke den for tiden herskende bibliometri-diskurs omend Dansk Universitetspædagogisk Tidsskrift naturligvis er nødt til at forholde sig til denne med henblik på at kunne fastholde en placering på listen over godkendte tidskrifter. Begrundelsen er primært, at vi ønsker at medvirke til at højne og kvalificere det universitetspædagogiske felt i forhold til teoretiske og videnskabelige standarder. Således er et centralt krav til artiklerne, at de, uanset om de bygger på empiriske studier eller mere teoretiske studier, på dybtgående vis kvalificerer det universitetspædagogiske felt med et kritisk, analyserende og diskuterende teoretisk perspektiv. Derudover skal der som vanligt være et vigtigt element i problemstillingen, som knytter an til anvendelse $i$ forhold til den universitetspædagogiske praksis. Vi arbejder for tiden med en revision af vores artikelkategorier. Der vil fremover være to kategorier: 1) Videnskabelige artikler inden for det universitetspædagogiske felt. 2) Formidling af undervisningspraksis relateret til universitetsundervis- ning. Artikler som af redaktionen bliver vurderet til at tilhøre kategori 1 vil blive underkastet en anonym fagfællebedømmelse (double-blind peer review).

Derudover vil tidsskriftet indeholde anmeldelser, debatindlæg og reportager. Beskrivelsen af kategorierne vil blive lagt på Dansk Universitetspædagogisk Tidsskrifts hjemmeside.

Dette nummer af Dansk Universitetspædagogisk Tidsskrift er det årlige konferencenummer, hvor temaet var Kvalitet i undervisning og uddannelse. En række af artiklerne bygger på papers og indlæg fra konferencen.

I Anne-Marie S. Christensens artikel, Kvalitetssikring, eksplicitisme og undervisererfaring, diskuteres det, hvorvidt forsøget på at kvalitetssikre universitetsundervisning faktisk understøtter kvaliteten af undervisningen. Artiklen tematiserer det spændingsfelt, der findes mellem de eksterne og kvantitative kriterier, der opstilles for undervisning, i artiklen beskrevet som eksplicitisme, og undervisningens erfaringsbaserede karakter. Undervisningens erfaringsbaserede karakter diskuteres via det filosofiske begreb praktisk fornuft.

I artiklen, Evaluering af evalueringer, diskuterer Gerd Christensen nogle af evalueringens konsekvenser, samt hvorvidt de måder, hvorpå konkrete evalueringsprocedurer udformes, kan have betydning for deres resultater i form af, hvordan de studerende vægter deres evaluering, og hvad de i realiteten evaluerer, når de evaluerer undervisning. I artiklen analyseres tre evalueringsprocedurer på det Humanistiske Fakultet, Københavns Universitet, og afslutningsvis giver forfatteren konkrete forslag til, hvorledes evalueringens fokus kan forskydes i retning af de studerendes evaluering af egen læring.

Hanne Nexø Jensen beskæftiger sig med en række centrale temaer knyttet til vejledning i artiklen, Det lukkede rum - en dør på klem til specialevejledning. Artiklen beskriver resultaterne af et pilotprojekt baseret på ti båndoptagede vejledningsmøder på Sam- 
fundsvidenskab. Projektet er interessant, fordi forfatteren har fået adgang til værdifuld viden om, hvordan specialevejledning reelt foregår - en viden som traditionelt holdes bag vejledningsrummets lukkede døre. Forfatteren finder bl.a., at vejlederne generelt er meget talende, og at dette især gælder de mandlige vejledere. Fundet rejser nogle grundlæggende spørgsmål om køn, styring og rollefordeling i vejledningsmøder.

Henrik Juels artikel, The Individual Art of Speaking Well, beskriver et eksperimenterende undervisningsforløb i retorik på Roskilde Universitetscenter. De studerende fik udfordringen, at skulle holde en tale på Speaker's Corner i London. I artiklen analyseres undervisningseksperimentet ud fra en didaktisk, kommunikationsteoretisk og sociokulturel vinkel. Endelig opridses, hvordan de i eksperimentet involverede principper er relevante for andre typer af universitetspædagogisk praksis.

Artiklen Studieplanlægning ved lægeuddannelserne, af Anne Mette Mørcke, Gitte WichmannHansen og Berit Eika, dokumenterer en undersøgelse (case studie og fokusgruppeinterview) af undervisernes rolle i studieplanlægning på lægeuddannelserne på de tre sundhedsvidenskabelige fakulteter i Århus, København og Odense. Artiklen konkluderer, at studielederne har en helt central rolle, og lektorerne en perifer rolle i den praktiske studieplanlægning. Forfatterne foreslår, at artiklen kan danne grundlag for at diskutere studieplanlægningspraksis.

Poul Thøis Madsens artikel, Hvordan skal man undervise ikke-økonomer i økonomi?, diskuterer, hvordan man bedst underviser i økonomi som redskabsfag. I artiklen argumenteres der for, at undervisningsformen gøres mere virkelighedsnær og verbaliseret, og at der undgås uakademisk undervisning $\mathrm{i}$ $ø$ konomiske 'sandheder', idet også økonomisk udvikling, debat og politik, ifølge Poul Thøis Madsen, bør være vigtige ingredienser $\mathrm{i} ø$ konomiundervisningen. Diskussionen tager udgangspunkt i og belyser 5 problemer, der er typiske for novicer i økonomi.

Derudover rummer dette nummer ideer til undervisningspraksis af Mette Liv Skovgaard samt en reportage af Lotte Rienecker og Peter Stray fra en europæisk konference om ph.d.-uddannelse. Endelig er der til sidst $i$ tidsskriftet anmeldelser af to bøger af interesse for det universitetspædagogiske felt samt en anmeldelse af en film indeholdende 12 filmvejledninger om virtuel studieteknik.

Vi modtager løbende artikelforslag. Retningslinjer, manuskriptvejledninger og beskrivelse af artikelkategorier findes på www.dun-net.dk. Send dit artikelforslag til merete.wiberg@learning.aau.dk. God skrive- og læselyst. 